\title{
The effect of iron on the invasiveness of Escherichia coli carrying the inv gene of Yersinia pseudotuberculosis
}

\author{
MARIA PIA CONTE, CATIA LONGHI, V. BUONFIGLIO, M. POLIDORO, LUCILLA SEGANTI \\ and PIERA VALENTI*
}

Institute of Microbiology, University of Rome "La Sapienza", Piazzale Aldo Moro 5, 00185 Rome and

*Institute of Microbiology, University of Naples, Italy

\begin{abstract}
Summary. The effect of growth in iron-excess or iron-limitation conditions on the invasiveness for HeLa cells of Escherichia coli HB101 carrying plasmid pRI203 which bears the invasion gene of Yersinia pseudotuberculosis was examined. Iron-limitation reduced adhesion and the number of organisms internalised by HeLa cells by about 100 -fold. The reduced adhesion of iron-starved bacteria correlated with reduced hydrophobicity and the reduced invasiveness appeared to depend on the plasmid copy number, which was $3 \cdot 5$-fold less than in bacteria grown in iron excess.
\end{abstract}

\section{Introduction}

The first step in the interaction between a pathogen and its host is attachment to the host cell surface but, while some bacteria remain on the surface, others proceed to penetrate the host cell. ${ }^{1}$

Tests of attachment and invasion in vitro are usually performed under standard nutritional conditions ${ }^{2}$ but it is possible that the nutrient status of the bacteria, with special reference to inorganic nutrients, may play an important role in the interaction. Little is known about the effect of ions on these processes. Thus, iron, as $\mathrm{Fe}^{3+}$, is an essential bacterial nutrient but, because it is insoluble at physiological $\mathrm{pH}$, its availability in vivo is poor $\left(10^{-18} \mathrm{M}\right) .^{3,4}$ The iron-binding proteins, transferrin and lactoferrin, play an important role in antibacterial defence by maintaining this low iron concentration. ${ }^{5}$

Bacteria isolated directly from infections have surface properties similar to those of iron-starved bacteria $^{6,7}$ and several studies have suggested that iron and iron-containing compounds enhance susceptibility to infection. ${ }^{8}$ However, little is known about the effect of iron overload on the pathogenicity of bacteria for mucosal cells. Thus, mucin, an iron carrier, increases survival of the vaccine strain of Vibrio cholerae during intestinal colonisation but the reason is not known. ${ }^{9}$

In Yersinia pseudotuberculosis, a $3 \cdot 2-\mathrm{kb}$ chromosomal region containing the inv gene is responsible for the ability of this organism to enter a wide variety of cell lines. ${ }^{2}$ The product of the inv gene is a 978-amino acid outer-membrane protein, invasin, which binds to

Received 4 Dec. 1992; revised version accepted 24 Sept. 1993.

* Correspondence should be sent to Dr P. Valenti. certain transmembrane proteins of mammalian cells (integrins). ${ }^{10,11}$ The inv gene has been cloned into plasmid pBR325 and the resulting plasmid, pRI203, has been introduced into the avirulent Escherichia coli strain HB101. ${ }^{12}$ The resulting strain, E. coli HB101 (pRI203), was able to invade HeLa cells but did not multiply intracellularly.

We have used $E$. coli HB101 (pRI203), grown in vitro under conditions of iron availability and iron restriction, to determine whether these conditions affect the ability of this organism to adhere to and invade HeLa cells.

\section{Materials and methods}

\section{Micro-organisms and media}

E. coli strain HB101 (pRI203) was kindly provided by Dr S. Falkow, Stanford Medical School, CA, USA. It carries a recombinant plasmid pRI203 into which a $Y$. pseudotuberculosis $3 \cdot 2-\mathrm{kb}$ chromosomal DNA fragment has been cloned and which renders $E$. coli $\mathrm{HB} 101$ invasive for cultured animal cells. ${ }^{12}$

E. coli $\mathrm{HB} 101$ and $E$. coli HB101 (pRI203) were grown in Trypticase Soy Broth (TSB; BBL) containing $20-50 \mu \mathrm{M} \mathrm{Fe}^{3+}$ as determined by atomic absorption spectrophotometry (Perkin-Elmer 360). Bacteria were also grown in minimal medium $\mathrm{M} 9$ plus thiamine $1 \mathrm{mg} / \mathrm{L}$, proline $40 \mathrm{mg} / \mathrm{L}$, threonine $40 \mathrm{mg} / \mathrm{L}$, leucine $40 \mathrm{mg} / \mathrm{L}$ and either $150 \mu \mathrm{M} 2,2^{\prime}$-dipyridyl as iron chelator for iron-limiting conditions or $50 \mu \mathrm{M} \mathrm{FeCl}_{3}$ for conditions of iron excess. In all experiments, ampicillin was added to a final concentration of $50 \mu \mathrm{g} / \mathrm{ml}$ to ensure maintenance of the recombinant plasmid. 


\section{Host cells}

HeLa $\mathrm{S}_{3}$ cells were grown at $37^{\circ} \mathrm{C}$ as monolayers in Eagle's Minimal Essential Medium (MEM; Gibco Laboratories) plus $\mathrm{NaHCO}_{3} 1 \cdot 2 \mathrm{~g} / \mathrm{L}, 2 \mathrm{~mm}$ glutamine, penicillin $100 \mathrm{U} / \mathrm{ml}$, streptomycin $0.2 \mathrm{mg} / \mathrm{ml}$ and heat-inactivated fetal calf serum $10 \%$ in a $\mathrm{CO}_{2} 5 \%$ atmosphere. Confluent monolayers were trypsinised and 24-well tissue culture plates (Costar) were loaded with $0.5 \mathrm{ml} /$ well of a suspension containing $1.5 \times 10^{5}$ cells $/ \mathrm{ml}$ and incubated in growth medium without antibiotics for $24 \mathrm{~h}$.

\section{Invasion and adherence assays}

Invasion of HeLa cells was assayed as described by Conte et al..$^{13}$ Briefly, HeLa cell monolayers $\left(3 \times 10^{5}\right.$ cells) were inoculated with $3 \times 10^{7}$ bacteria in basal Eagle's medium (BME) for $90 \mathrm{~min}$ at $37^{\circ} \mathrm{C}$. The monolayers were then washed and fresh BME, containing gentamicin $50 \mu \mathrm{g} / \mathrm{ml}$, was added to kill extracellular bacteria. After incubation for $2 \mathrm{~h}$ at $37^{\circ} \mathrm{C}$, the cells were lysed to determine the number of viable internalised bacteria by colony counts.

In other experiments, duplicate assays were performed in which infection was synchronised by a temperature shift. Bacteria $\left(3 \times 10^{7}\right)$ were added to precooled cells $\left(3 \times 10^{5}\right)$ and incubated for $90 \mathrm{~min}$ at $4^{\circ} \mathrm{C}$. After infection, the cells were washed carefully to remove unattached bacteria and then lysed to determine the number of bound bacteria by colony counts. In another experiment the temperature was raised to $37^{\circ} \mathrm{C}$ after infection to allow bacteria bound at $4^{\circ} \mathrm{C}$ to penetrate $\mathrm{HeLa}$ cells. After incubation for $60 \mathrm{~min}$, gentamicin-containing medium was added for $2 \mathrm{~h}$. After lysis, the number of internalised bacteria was determined by colony counts.

The results of adherence and invasion assays from five independent experiments performed in triplicate were collected. The mean value and SD were determined for each assay.

\section{Adherence of fluorescein-labelled bacteria}

Fluorescein isothiocyanate (FITC; Sigma), dissolved in phosphate-buffered saline (PBS), $\mathrm{pH} 8.0$, at a concentration of $2 \mathrm{mg} / \mathrm{ml}$, was incubated with $2 \times 10^{7}$ bacteria $/ \mathrm{ml}$ at room temperature for $15 \mathrm{~min}$. The bacteria were then washed twice in PBS by centrifugation at $5000 \mathrm{~g}$. A suspension of $1 \times 10^{7}$ FITC-labelled bacteria plus Evans blue $0.001 \%$ was added to semiconfluent monolayers and left in contact for $2 \mathrm{~h}$. The monolayers were washed five times, fixed in formaldehyde $1 \%$ and adherent organisms were observed by microscopy.

\section{Hydrophobic interaction chromatography}

Bacteria were loaded on to octyl-sepharose columns (Pharmacia Fine Chemicals) according to a minor modification of the procedure described by Ohman et al. ${ }^{14}$ Briefly, pasteur pipettes were filled with $1 \mathrm{ml}$ of octyl-sepharose and equilibrated with $0.1 \mathrm{M}$ $\left(\mathrm{NH}_{4}\right)_{2} \mathrm{SO}_{4}$ buffer ( $\mathrm{pH} \mathrm{7 \cdot 0)}$. The bacterial suspensions $\left(10^{8}\right.$ cells $\left./ 100 \mu \mathrm{l}\right)$, washed three times with the above buffer, were applied on to the gel and eluted with $0 \cdot 1 \mathrm{M}$ $\left(\mathrm{NH}_{4}\right)_{2} \mathrm{SO}_{4}$. The retention of the cells reflected a hydrophobic interaction and was expressed as the percentage of bacteria retained. In control experiments octyl-sepharose columns were equilibrated and eluted with distilled water.

\section{Analysis of outer-membrane proteins (OMP)}

Bacteria (100 mg dry weight) harvested in late exponential phase were suspended in $1 \mathrm{ml}$ of $30 \mathrm{mM}$ Tris- $\mathrm{HCl}, \mathrm{pH} 8.0$, and disrupted by three cycles of $1 \mathrm{~min}$ each of sonication (18 $\mathrm{mHz}$ at Soniprep 150) on ice. Cell debris was removed by centrifugation (15 $\mathrm{min}$ at $5000 \mathrm{~g}$ ), the inner membranes were solubilised with sodium-laurylsarcosinate $1 \%$ and the OMPs were collected by centrifugation at $51000 \mathrm{~g}$ for $1 \mathrm{~h}$ at $4^{\circ} \mathrm{C}$. SDS-PAGE was performed under denaturation conditions in a resolving $8 \%$ gel with a stacking $5 \%$ gel. $^{15}$

\section{Extraction and electrophoresis of total nucleic acids}

Briefly, bacteria from $5 \mathrm{ml}$ of bacterial culture, in late exponential phase, were harvested by centrifugation at $5000 \mathrm{~g}$ for $10 \mathrm{~min}$ at $4^{\circ} \mathrm{C}$ and washed in $1 \times \mathrm{TE}$ (10 mm Tris-HCl, pH 7.5, $1 \mathrm{~mm}$ EDTA, pH 8.0). The cell pellet was suspended in $260 \mu$ l of sucrose $25 \%$ $50 \mathrm{mM}$ Tris- $\mathrm{HCl}, \mathrm{pH} 7 \cdot 5$, containing lysozyme $1 \mathrm{mg} /$ $\mathrm{ml}$ and kept for $5 \mathrm{~min}$ at $0^{\circ} \mathrm{C}$. Then $300 \mu \mathrm{l}$ of Triton $\mathrm{X} 1001 \%$, $50 \mathrm{~mm}$ Tris- $\mathrm{HCl}$, pH 8.0, $20 \mathrm{~mm}$ ribonucleoside vanadyl complexes (Sigma) were added and the sample was held for $5-10 \mathrm{~min}$ at $0^{\circ} \mathrm{C}$. After centrifugation at $42000 \mathrm{~g}$ for $20 \mathrm{~min}$ at $4^{\circ} \mathrm{C}$, the cleared lysate was extracted four times with an equal volume of PCI (phenol $50 \%$ saturated with $50 \mathrm{~mm}$ Tris- $\mathrm{HCl}$, pH 7.5; chloroform $48 \%$; iso-amyl alcohol $2 \%$ ) and precipitated twice for $30 \mathrm{~min}$ at $-70^{\circ} \mathrm{C}$ with $0 \cdot 1 \mathrm{vol}$ of $3 \cdot 3 \mathrm{M}$ sodium acetate, $\mathrm{pH} 5 \cdot 2$, and 3 vols of absolute ethanol.

Nucleic acids were dissolved in double-distilled water containing diethyl pyrocarbonate $0.5 \%$ and stored at $-70^{\circ} \mathrm{C}$. Nucleic acids were dissolved in formaldehyde $7.5 \%$, formamide $20 \%, 1 \times$ MOPS (20 mM 3[N-morpholino]propone-sulphonic acid, $5 \mathrm{~mm}$ sodium acetate, $\mathrm{pH} 7 \cdot 0,1 \mathrm{~mm}$ EDTA, pH 8.0) and incubated for $10 \mathrm{~min}$ at $65^{\circ} \mathrm{C}$. Electrophoresis was performed in agarose $1 \%-1 \times$ MOPS gel containing formaldehyde $6 \%$.

\section{Hybridisation procedures}

After electrophoresis, nucleic acids were transferred by capillary blotting on to Hybond-C nitrocellulose membranes (Amersham) and filters were treated according to the recommendations of the manufacturer. The invasin gene, kindly provided by Dr A. Crisanti 

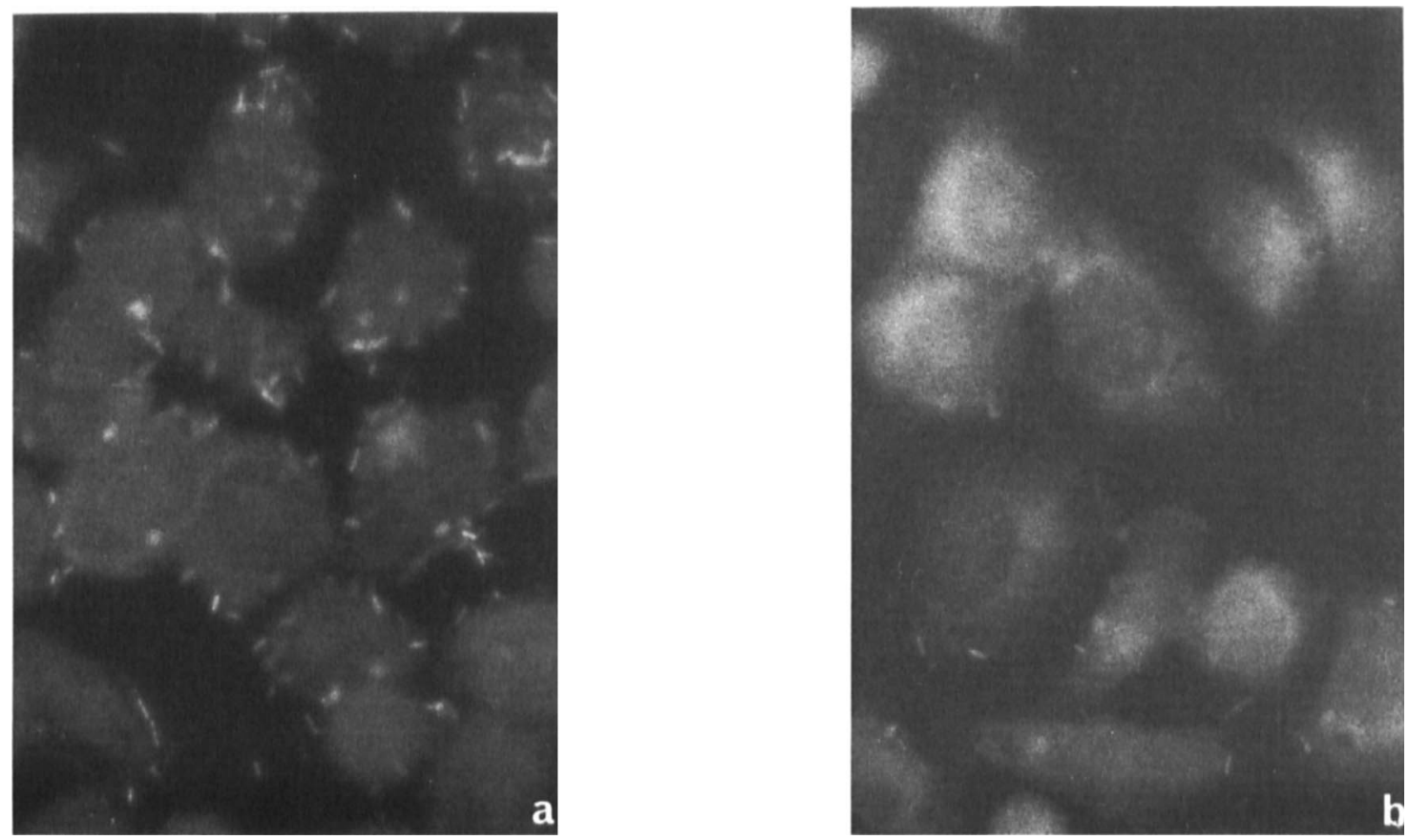

Fig. 1. Binding of FITC-labelled E. coli HB101 (pRI203) to HeLa cells after 90 min at $4^{\circ} \mathrm{C}$; a, grown in iron excess; b, grown in iron-limiting conditions.

(Institute of Parasitology, University of Rome), was labelled with ${ }^{32} \mathrm{P}$-dATP with a Random Primed DNA Labelling Kit (Boehringer Mannheim) and unincorporated nucleotides were removed on Quick Spin columns G-50 Sephadex (Boehringer Mannheim). After hybridisation, filters were washed to remove non-specific binding of DNA according to the method of Sambrook et al. ${ }^{16}$

Table I. Invasion of HeLa cells by E. coli HB101 (pRI203) grown under different conditions of iron availability

\begin{tabular}{lc}
\hline Growth conditions & $\begin{array}{c}\text { Mean (SD) number of } \\
\text { viable internalised bacteria* } \\
\text { (cfu) }\end{array}$ \\
\hline TSB (20-50 $\mathrm{M} \mathrm{Fe}^{3+}$ ) & $2 \cdot 0(0 \cdot 37) \times 10^{5}$ \\
M9 plus $50 \mu \mathrm{M} \mathrm{F}^{3+}$ & $1 \cdot 1(0 \cdot 45) \times 10^{5}$ \\
M9 plus $150 \mu \mathrm{M} \mathrm{2,2'-dipyridyl}$ & $1 \cdot 2(0 \cdot 70) \times 10^{3}$
\end{tabular}

*Mean values of intracellular bacteria $/ 3 \times 10^{5} \mathrm{HeLa}$ cells derived from five independent experiments.

\section{Results}

The adherence of FITC-labelled organisms placed in contact with cell monolayers at $4^{\circ} \mathrm{C}$ for $120 \mathrm{~min}$ is illustrated in fig. 1. Bacteria grown in iron excess adhered better $\left(1.2 \times 10^{3} / 100 \mathrm{HeLa}\right.$ cells; fig. 1a) than those grown under iron-limiting conditions (50/100 HeLa cells; fig. 1b).

In the standard penetration assay, a mean of $2 \times 10^{5}$ $E$. coli HB101 (pRI203) bacterial cells were internalised by $3 \times 10^{5} \mathrm{HeLa}$ cells. The efficiency of penetration was increased when the bacteria were centrifuged on to the cell monolayers or when the period of infection was increased. The results obtained with organisms after six serial passages in medium M9 supplemented with $50 \mu \mathrm{M} \mathrm{FeCl}_{3}$ or with $150 \mu \mathrm{M} 2,2^{\prime}$-dipyridyl are shown in table I. This shows that organisms grown under iron limitation had a reduced ability to penetrate HeLa cells compared with those grown in iron excess.

Adherence and cell invasion were also studied by determination of viable counts in a temperature shift

Table II. Adherence and penetration into HeLa cells of E. coli HB101 (pRI203) grown under different conditions of iron availability

\begin{tabular}{lcc}
\hline Growth conditions & $\begin{array}{c}\text { Mean (SD) number of } \\
\text { bound bacteria } 3 \times 10^{5} \\
\text { HeLa cells (cfu) }\end{array}$ & $\begin{array}{c}\text { Mean (SD) number of } \\
\text { internalised bacteria } \\
\text { (cfu) }\end{array}$ \\
\hline TSB $\left(20-50 \mu \mathrm{M} \mathrm{Fe}^{3+}\right)$ & $3.0(1 \cdot 12) \times 10^{6}$ & $5.4(0.45) \times 10^{5}$ \\
M9 plus $50 \mu \mathrm{M} \mathrm{Fe}{ }^{3+}$ & $1 \cdot 4(0 \cdot 95) \times 10^{6}$ & $2 \cdot 5(0 \cdot 64) \times 10^{5}$ \\
M9 plus $150 \mu \mathrm{M}$ & $1 \cdot 3(0 \cdot 78) \times 10^{4}$ & $2 \cdot 6(0 \cdot 55) \times 10^{3}$ \\
2,2'-dipyridyl & & \\
\hline
\end{tabular}




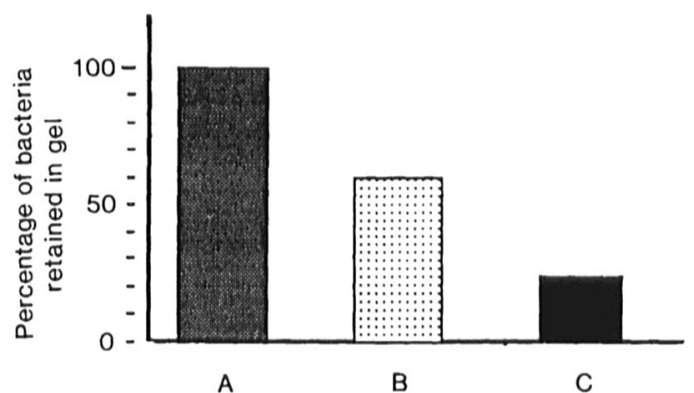

Fig. 2. Percentage of bacteria retained in an octyl-sepharose gel $E$. coli HB101 (pRI203) grown in iron excess-A, TSB with 20-50 $\mu \mathrm{M} \mathrm{Fe}^{3+} \square, \mathrm{B}, \mathrm{M} 9$ plus $50 \mu \mathrm{M} \mathrm{Fe} e^{3+}$-or, $\mathrm{C}$, in iron-limiting conditions- $\mathrm{M} 9$ plus $150 \mu \mathrm{M} 2,2^{\prime}$-dipyridyl

experiment. The results are given in table II. Both adherence and cell invasion were greater with organisms grown in TSB or in iron excess.

The effect of iron availability during growth on the surface hydrophobicity of $E$. coli HB101 (pRI203) is shown in fig. 2 . Some $60 \%$ of organisms grown in iron excess were retained on the octyl-sepharose column, in contrast to $25 \%$ of those grown under iron restriction. The results obtained with the non-invasive $E$. coli HB101 were similar.

The OMP profiles of the invasive and non-invasive strains grown under iron-limiting and iron-excess conditions are shown in fig. 3. Under iron-limiting conditions, both strains produced OMPs of 74, 76 and $81 \mathrm{kDa}$. The function of the $76-\mathrm{kDa}$ protein is unknown but the 74- and $81-\mathrm{kD}$ a proteins are known to be receptors for colicin I and ferric enterochelin, respectively. ${ }^{6,17,18}$ The $103-\mathrm{kDa}$ protein band, corresponding to the invasin of $E$. coli HB101 (pRI203), was not observed in these experiments.

Determinations of the plasmid copy number of organisms grown under conditions of iron restriction and excess with the same amount of DNA from each type of organism subjected to electrophoresis and blotted on to nitrocellulose and hybridised with ${ }^{32} \mathrm{P}$ labelled invasin gene, showed that the signal from iron replete organisms was 3.5-fold greater than that for organisms grown under iron restriction.

\section{Discussion}

Infection induces a state of hypoferraemia and bacteria isolated from sites of infection are similar to those grown in culture under iron restriction. ${ }^{8}$ Therefore, it was of interest to determine the effect of iron deprivation in vitro on the expression of bacterial virulence factors. Several studies have shown that iron-stressed pathogenic bacteria have evolved mechanisms, such as siderophore synthesis, for the acquisition of iron. ${ }^{817}$ However, little information is available about the modulation by iron of the factors involved in the attachment and penetration of cells by enteropathogens. In particular, it is still unclear how iron overload, which increases susceptibility to bacterial infections, ${ }^{3}$ interferes with host defence mechanisms or with bacterial virulence factors, or both.

The results reported here show that $E$. coli $\mathrm{HB} 101$ (pRI203) grown in iron-deficient medium has a reduced ability to bind to and penetrate HeLa cells. In a manner similar to that of other iron-starved bacteria, E. coli HB101 and HB101 (pRI203) showed OMP changes corresponding to the synthesis of OMPs of 74, 76 and $81 \mathrm{kDa}$. Although the function of the $76-\mathrm{kDa}$ protein is unknown, the $74-$ and $81-\mathrm{kDa}$ proteins are known to be the receptors for colicin I and enterochelin..$^{6,17,18}$ As these OMPs are expressed

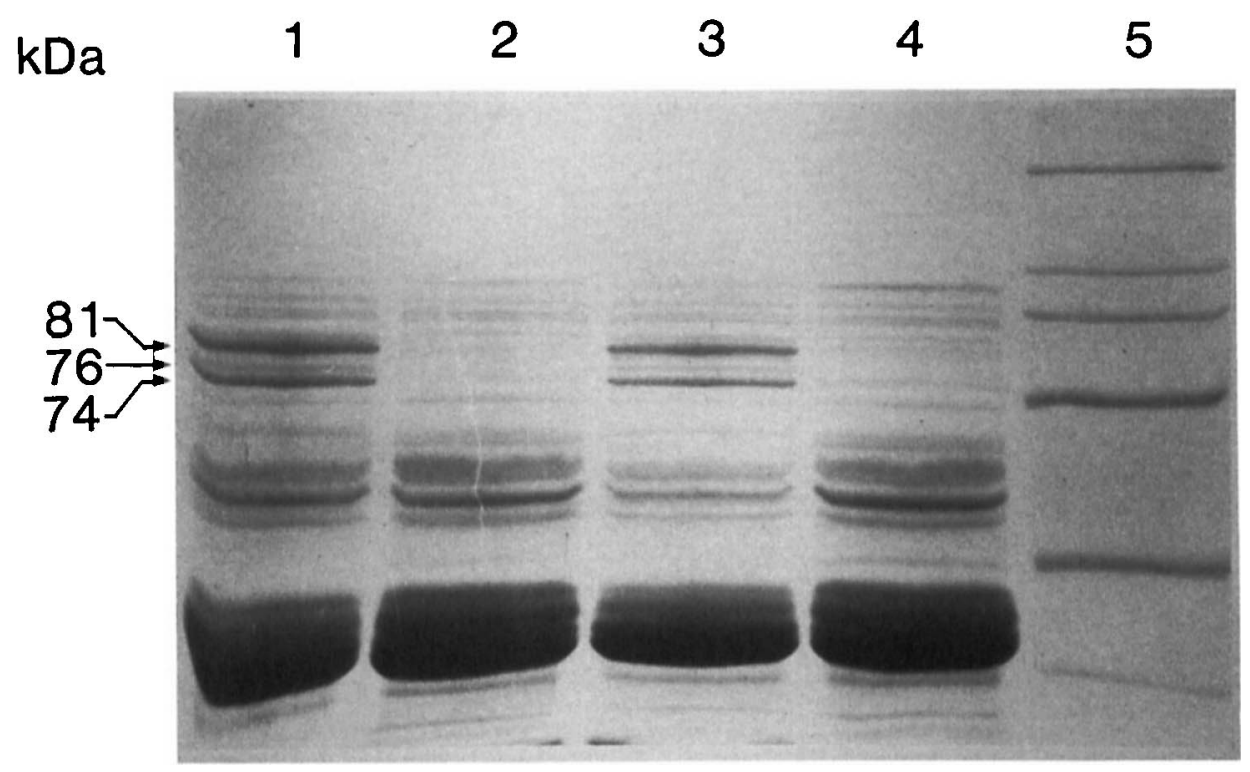

Fig. 3. SDS-PAGE of OMPs of $E$. coli HB101 (pRI203) (lanes 1 and 2) and of the non-invasive strain $E$. coli HB101 (lanes 3 and 4), grown in iron-excess (lanes 2 and 4) or iron-limiting conditions (lanes 1 and 3). Lane 5: mol. wt markers (BioRad): myosin (200 kDa), E. coli $\beta$ galactosidase $(116.25 \mathrm{kDa})$, rabbit muscle phosphorylase b $(97.4 \mathrm{kDa})$, bovine serum albumin $(66.2 \mathrm{kDa})$, hen egg white ovalbumin $(42.7 \mathrm{kDa})$ and bovine carbonic anhydrase $(31.0 \mathrm{kDa})$. The arrows indicate the three proteins expressed in iron-limiting conditions. 
equally by invasive and non-invasive $E$. coli strains, they are probably not involved in the early phases of invasion.

It was observed that the hydrophobicity of organisms was markedly reduced by iron restriction. This may be due to the induction of exopolysaccharide production by iron restriction, as has been suggested by others. ${ }^{19,20}$ This lower hydrophobicity seems to contribute to a decrease of the invasion efficiency by acting on the adhesion step.

As $E$. coli HB101, which lacks the inv gene, is incapable of penetrating HeLa cells, it may be that the

\section{References}

1. Finlay BB, Falkow S. Common themes in microbial pathogenicity. Microbiol Rev 1989; 53: 210-230.

2. Isberg RR. Pathways for the penetration of enteroinvasive Yersinia into mammalian cells. Mol Biol Med 1990; 7: 73-82.

3. Finkelstein RA, Sciortino CV, McIntosh MA. Role of iron in microbe-host interactions. Rev Infect Dis 1983; 5 Suppl: S759-S777.

4. Earhart CF. Ferrienterobactin transport in Escherichia coli. In: Winkelmann G, Van der Helm D, Neilands JB (eds) Iron transport in microbes, plants and animals. VCH Verlagsgesellschaft Weinheim. 1987: 67-84.

5. Dennis Chasteen N, Woodworth RC. Transferrin and lactoferrin. In: Prem Ponka H, Shulman M, Woodworth RC (eds) Iron transport and storage. Boca Raton, FL, CRC Press. 1990: 67.

6. Griffiths E, Stevenson P, Joyce P. Pathogenic Escherichia coli express new outer membrane proteins when growing in vivo. FEMS Microbiol Lett 1983; 16: 95-99.

7. Brown MRW, Anwar H, Lambert PA. Evidence that mucoid Pseudomonas aeruginosa in the cystic fibrosis lung grows under iron-restricted conditions. FEMS Microbiol Lett 1984; 21 : 113-117.

8. Cox $C D$. Importance of iron in bacterial virulence. In: Beveridge TJ, Doyle RJ (eds) Metal ions and bacteria. New York, John Wiley and Sons. 1989: 207-246.

9. Ford A, Hayhoe JPV. An investigation of alternatives to hog gastric mucin or virulence-enhancing agents in the cholera vaccine potency assay. $J$ Biol Stand $1976 ; 4$ : 353-366.

10. Isberg RR, Voorhis DL, Falkow S. Identification of invasin: a protein that allows enteric bacteria to penetrate cultured mammalian cells. Cell 1987; 50: 769-778. most important factor in the invasion process under different iron-availability conditions is the significant change of the copy number of plasmid pRI203. This is consistent with our observation that iron-stressed bacteria had a lower plasmid copy number than bacteria grown in iron excess, and also a decreased expression of invasin.

We thank Dr S. Falkow for providing the $E$. coli $\mathrm{HB} 101$ (pRI203) strain, Dr A. Crisanti for producing the inv probe and Professor C. Romano Caratelli for her helpful contribution to hydrophobic chromatography assays. This research has been carried out with Ente Nazionale Energie Alternative (ENEA), Ministero Pubblica Istruzione (MPI) and CNR grants.

11. Leong JM, Fournier RS, Isberg RR. Identification of the integrin binding domain of the Yersinia pseudotuberculosis invasin protein. EMBO J 1990; 9: 1979-1989.

12. Isberg RR, Falkow S. A single genetic locus encoded by Yersinia pseudotuberculosis permits invasion of cultured animal cells by Escherichia coli K-12. Nature 1985; 317: $262-264$.

13. Conte MP, Mastromarino $\mathbf{P}$, Nicoletti $\mathbf{M}$, Visca $\mathbf{P}$, Valenti $\mathbf{P}$, Seganti L. Effect of polyelectrolytes on entry of Escherichia coli HB101 (pRI203) into HeLa cells. Microb Pathog 1990; 9: 191-198.

14. Öhman L, Normann B, Stendahl O. Physicochemical surface properties of Escherichia coli strains isolated from different types of urinary tract infections. Infect Immun 1981; 32: 951-955.

15. Laemmli UK. Cleavage of structural proteins during the assembly of the head of bacteriophage T4. Nature 1970; 227: 680-685.

16. Sambrook J, Fritsch EF, Maniatis T. Molecular cloning: a laboratory manual, 2nd edn. Cold Spring Harbor, NY, Cold Spring Harbor Laboratory Press. 1989.

17. Neilands JB. Siderophore systems of bacteria and fungi. In: Beveridge TJ, Doyle RJ (eds) Metal ions and bacteria. New York, John Wiley and Sons. 1989: 141-163.

18. Neilands JB. Microbial envelope proteins related to iron. Annu Rev Microbiol 1982; 36: 285-309.

19. Craven DE, Peppler MS, Frasch CE, Mocca LF, McGrath PP, Washington G. Adherence of isolates of Neisseria meningitidis from patients and carriers to human buccal epithelial cells. J Infect Dis $1980 ; 142$ : 556-568.

20. Brown MRW, Williams P. The influence of environment on envelope properties affecting survival of bacteria in infections. Annu Rev Microbiol 1985; 39: 527-556. 